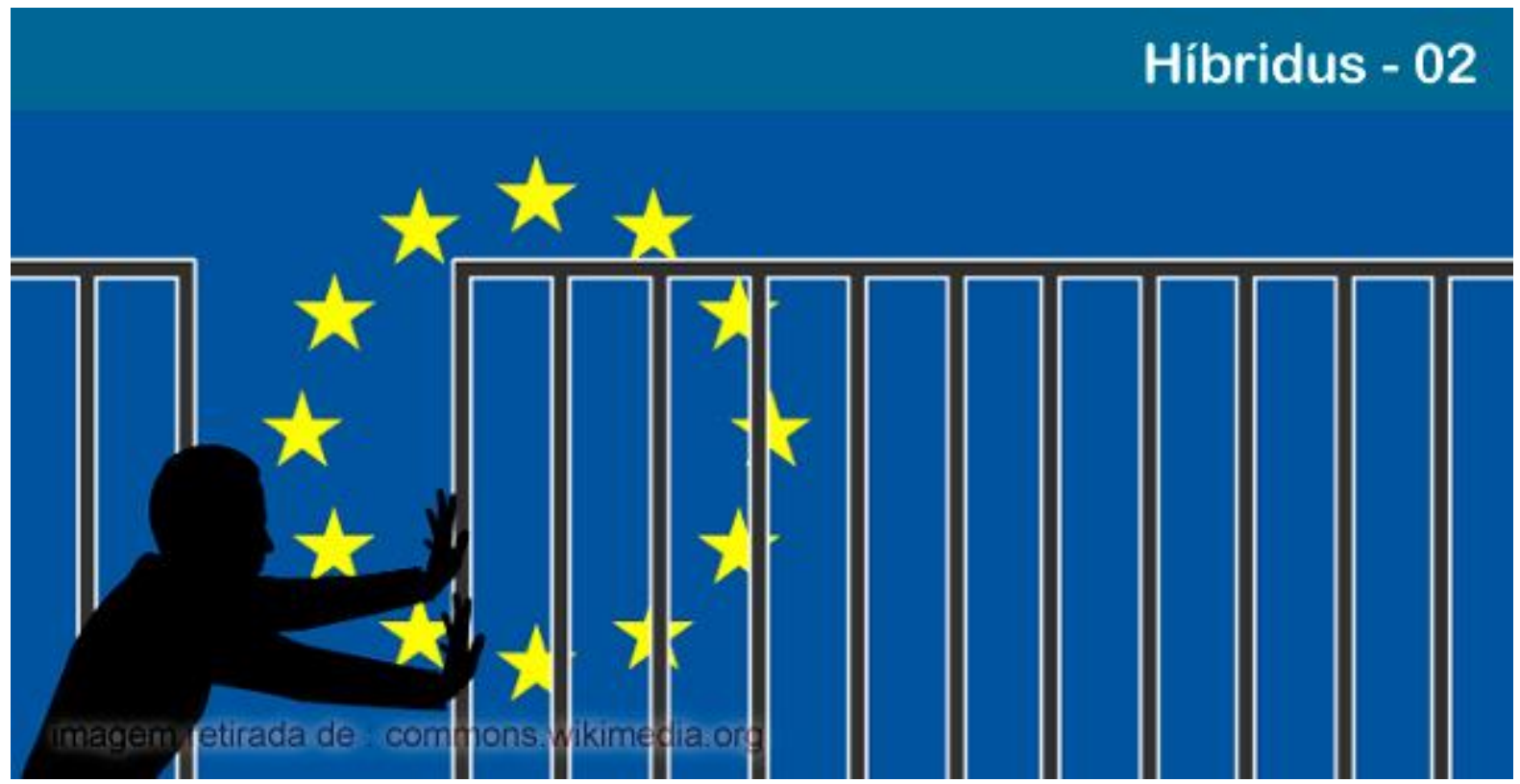

\title{
O MOVIMENTO TRANSEUROPEU DA ESQUERDA RADICAL DEMOCRÁTICA E O PROBLEMA DOS REFUGIADOS/MIGRANTES
}

\section{Henrique Garcia Pereira}

Instituto Superior Técnico, Lisboa.E-mail: henrique.pereira@ist.utl.pt.

Resumo: Descrevem-se algumas facetas de um novo movimento transeuropeu - DiEM25 (Democracy in Europe Movement 2025) - que surgiu em Berlim (Fevereiro 2016) com o objetivo de modificar 'por dentro' a União Europeia, no sentido da esquerda democrática e plural. Referem-se as diferentes assembleias que percorreram a Europa no âmbito deste movimento, desde Madrid até Viena (5 de Maio, 2016). A partir dos temas tratados neste último encontro, com o motto "Europe's Duty to the Refugees, Europe's Duty to itself", são discutidas as alternativas de esquerda para o problema dos refugiados, e avaliada criticamente a não-solução proposta pelas instituições europeias.

Palavras-chave: DiEM25. Encontros pan-europeus à esquerda. Refugiados/migrantes.

\section{THE RADICAL DEMOCRATIC LEFT-WING PAN-EUROPEAN MOVEMENT ANT THE REFUGEES/MIGRANTS ISSUE}

Abstract: Since its presentation in Berlin (February 2016), some facets of a new pan-European movement DiEM25 (Democracy in Europe Movement 2025) - are described, showing how it aims to modify 'from inside' the European Union, moving it forward to radical democratic left-wing positions. A sequence of Forums in the scope of the movement are commented, from Madrid to Vienna (May 5, 2016), being the last one - under the motto "Europe's Duty to the Refugees, Europe's Duty to itself " - the basis for a discussion on the left-wing alternatives to the refugees issue, in addition to a critical assessment of the non-solution proposed by European Institutions.

Keywords: DiEM25. Left-wing pan-European meetings. Refugees/migrants.

\section{Introdução}

Sabe-se como o poder neoliberal da União Europeia (UE) levantou barreiras atrás de barreiras à soberania da Grécia, dirigida pelo Syriza, aquando da intervenção da Troika

\section{POLÊM!CA $\mid$ LABORE}

Polêmica - Revista Eletrônica da Uerj - Rua São Francisco Xavier, 524, $1^{\circ}$ andar

bloco D, sl.1001 • Tels.: +55 21 2334-4088/4087 • http://www.e-publicacoes.uerj.br/index.php/polemica/index

http://www.labore.uerj.br • laboreuerj@yahoo.com.br 
$($ Eurogrupo + Banco Central Europeu + FMI), e como o governo se desmultiplicou em eleições e referendos (sempre triunfantes) para se manter no Euro, respeitando simultaneamente a sua política democrática e reformista (Fig. 1).

Figura - 1: A democracia de Tsipras combina-se com o Euro

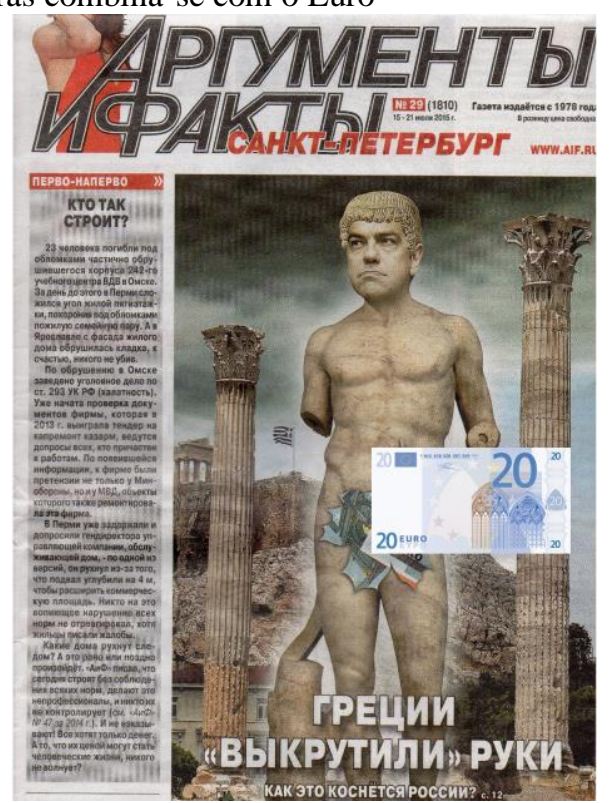

Fonte: Détournement da folha de rosto do jornal oficial do KKE (partido comunista ortodoxo, que defende a saída do Euro).

Uma dinâmica política similar, mutatis mutandis, está a desenvolver-se em Portugal, onde um Governo PS (Partido Socialista) é suportado no Parlamento por uma maioria que abarca o Bloco de Esquerda (BE - formação urbana de esquerda democrática e radical que teve $10 \%$ dos votos nas eleições de dezembro de 2015) e o Partido Comunista Português (PCP - formação de cariz institucional não-golpista com forte implantação nos meios mais 'quadrados', e que obteve $8 \%$ nas últimas legislativas).

O BE é severamente diabolizado pela direita, que o vê como responsável pelo impulso que 'empurrou' para a esquerda o PS, outrora dócil para enquadrar quaisquer 'Blocos Centrais’ e outras coligações no sentido dextrogiro. Agora no poder, o BE era, ainda há poucos meses, visto pelos reacionários como uma espécie de grupo de 'animadores culturais' (em que se destacavam as posições LGBT), apresentando propostas de temas 'fraturantes' (aborto livre e gratuito, casamento de pessoas do mesmo sexo, direitos das minorias, ...), mas

\section{POLÊM!CA $\mid$ LABORE}


aparentemente inócuos ${ }^{1}$ para o que realmente parecia interessar à clique de direita, ou seja, os seus privilégios económico-financeiros.

Em Portugal ${ }^{2}$, também a população é a favor da manutenção do Euro, cumprindo ao mesmo tempo um programa que favorece os mais desfavorecidos, o que corresponde à intersecção dos programas eleitorais dos 3 partidos que apoiam o governo de António Costa, o socialista cuja primeira 'viagem de estado' teve como objetivo manifestar a sua solidariedade com o Syriza, a propósito do problema dos refugiados (Fig. 2).

Figura - 2: António Costa e Alexis Tsipras

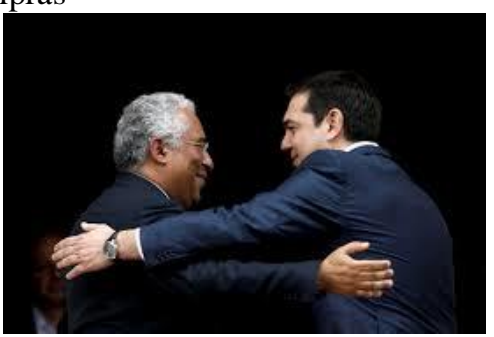

Fonte: "Público" 12 de abril 2016.

Paralelamente à Grécia, a nova política portuguesa está em contramão com uma persistente e sournoise intervenção do Euro-grupo (e outras instituições não-eleitas) que clama pela 'flexibilização' do trabalho, pelo corte nos salários e pensões, pela extinção progressiva do 'estado social' (em suma, pelo que convencionou chamar 'austeridade' à maneira alemã, $v d$. Fig. 3).

\footnotetext{
${ }^{1}$ Miguel Vale de Almeida, num encontro realizado a 10 de Maio de 2016 na Fundação Gulbenkian (sob a sugestiva divisa "HUMAN RIGHTS, Globalizing Dignity"), chamou a atenção para a importância antropológica desses temas ditos 'fraturantes'. Por exemplo, se o movimento LGBT é amplamente reconhecido nos países 'mais desenvolvidos', "é preciso que esse fato - que deve ser tomado como 'corriqueiro' - não seja usado para marcar a contrario alguma 'superioridade' em face dos países do ex-terceiro-mundo, onde esses direitos são espezinhados, e têm de ser apoiados". Especialista em antropologia pós-colonial, este acadêmico tem uma extensa obra com certos laivos de pioneirismo, em que alguns tópicos originais são aflorados sob uma perspectiva verdadeiramente 'fraturante' (por exemplo, a etnografia do movimento afrocultural numa cidade baiana (cf. ALMEIDA, 2000, p. 27).

${ }^{2}$ É estranhamente similar, neste milénio, uma série de aspetos que aproximam simbolicamente a Grécia de Portugal, de um e outro lado do Mediterrâneo (PEREIRA, 2008). Para lá da intervenção em (quase) uníssono da Troika, desde uma população e um PIB da mesma ordem de grandeza até às rivalidades entre a primeira e a segunda cidade de cada país (Atenas vs. Salónica, Lisboa vs. Porto), passando pela geomorfologia, vegetação, hospitalidade, emigração intensa, poesia e canto nostálgico (fado vs. rembetika)..., os dois países são surpreendentemente parecidos, para lá da geografia oposta (e uma certa cumplicidade se estabelece entre as esquerdas de cá e de lá, enquanto as direitas tendem a distanciar-se, com base em slogans depreciativos para o país simétrico: liminarmente, "Portugal não é a Grécia", num sentido, e, no contrário, "a Grécia, berço da democracia, não se compara com um país que só tem laranjeiras" (em grego, o nome portugalia é afim de laranja).
}

\section{POLÊM!CA | LABORE (S:}

Polêmica - Revista Eletrônica da Uerj - Rua São Francisco Xavier, 524, $1^{\circ}$ andar

bloco D, sl.1001 • Tels.: +55 21 2334-4088/4087 • http://www.e-publicacoes.uerj.br/index.php/polemica/index http://www.labore.uerj.br • laboreuerj@yahoo.com.br 
É como se a UE, para estes dois países (em que uma certa esquerda está no poder) e para outros (em que está próxima, como em Espanha), funcionasse como uma MÃE (da vulgata freudiana) manipuladora, possessiva e autoritária, mas ligada aos 'filhos' por uma relação umbilical de amor-ódio que estes não querem cortar. O Papa Francisco, no seu discurso de aceitação do prémio Carlos Magno - que lhe foi outorgado em 05.05.2016 pela União Europeia (UE) para oficiar (quase religiosamente) um argentino na condição de 'europeu de excelência' - criticou as instituições que o agraciavam, tomando-as também como uma MÃE que mata os seus próprios filhos (numa rebuscada Medeialógica que não deixaria Eurípedes ficar mal). Se quisermos uma interpretação mais despoetizada e não-mítica (já que se diz que a vulgata psicanalítica consiste numa combinatória dos órgãos genitais com os mitos gregos), a dependência de cada estado-nação europeu relativamente à UE pode ser vista prosaicamente como o resultado da necessidade de se integrar numa 'rede' (embora esburacada), capaz de enfrentar (ou pelo menos conviver com) a inevitável globalização, para além de beneficiar alguns 'privilégios' de tendência inclusiva, mas cada vez menos vigorosos (o Programa Erasmus de boa memória tem cada vez mais exigências limitativas, o espaço Schengen da bendita livre circulação de pessoas e bens assiste - estupefacto - ao estabelecimento de fronteiras de arame-farpado no seu interior...).

O que é fato é que a UE tende a 'castigar' UM qualquer país que se afaste (isoladamente) dos cânones neoliberais. Esta atitude política sistemática levou a que se pensasse na criação de um movimento plurinacional, cosmopolita e democrático que combatesse, por dentro e solidariamente, o diktat arbitrário e enganoso (Fig. 3) das instituições não-eleitas ao serviço, na Europa, dos tais $1 \%$ que governam o Mundo com uma impiedade e fereza sem limites ${ }^{3}$. Este movimento começou no Sul, sob o signo da negação militante da 'austeridade' (Fig. 4), e tende a "lançar um enxame de vespas no confessionário", na fórmula bien trouvée de Monedero (2013). Trata-se de criar um novo "paradigma ontológico", na linha de Laclau \& Mouffe (2013), formando um espaço discursivo dotado de uma nova terminologia, oposta à que transparece da Fig. 3.

Figura - 3: O ministro das finanças alemão comanda a semântica

\footnotetext{
3 A este propósito, comparando a 'crise' atual com a de 1929, Monedero (2013) comenta que alguns robber barons de Wall Street se atiraram pela janela dos arranha-céus na primeira 'crise', enquanto que, na de hoje, criaram as condições para que alguns dos $99 \%$ façam coisa semelhante (sob diferentes formas, já que é mais raro o acesso aos arranha-céus por parte da 'gente').
}

\section{POLÊM!CA $\mid$ LABORE}



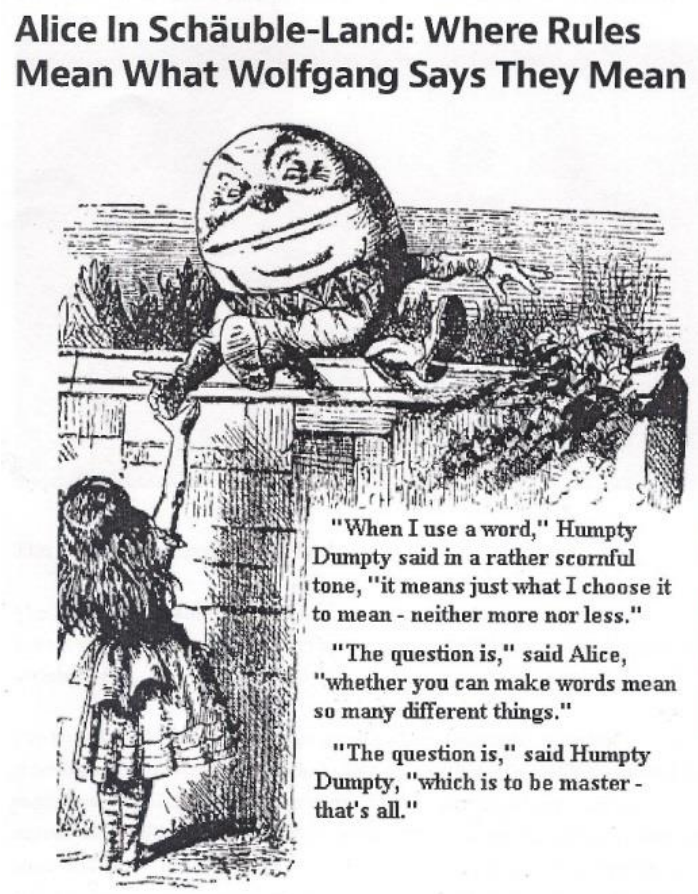

Fonte: https://medium.com/bull-market/alice-in-schäuble-land-where-rules.

Figura - 4: Contra a austeridade

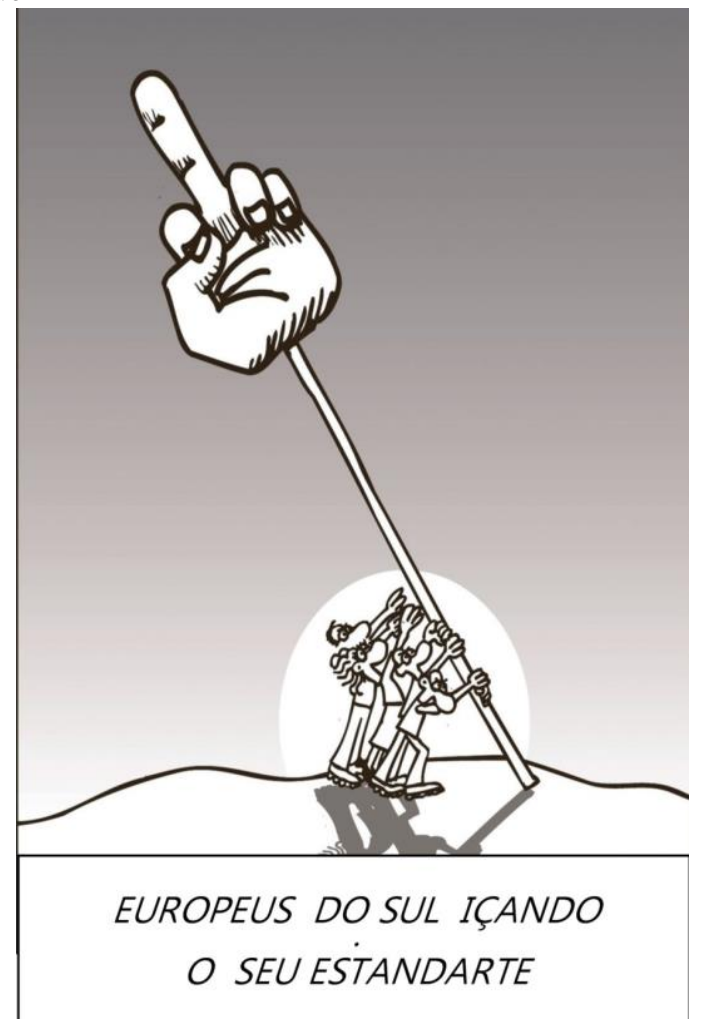

Fonte: Adaptado de "El País”, 24 de novembro de 2014.

\section{POLÊM!CA LABORE (3)}

Polêmica - Revista Eletrônica da Uerj - Rua São Francisco Xavier, 524, $1^{\circ}$ andar bloco D, sl.1001 • Tels.: +55 21 2334-4088/4087 • http://www.e-publicacoes.uerj.br/index.php/polemica/index http://www.labore.uerj.br • laboreuerj@yahoo.com.br 
Tal iniciativa parece o 'ovo de Colombo', de tal maneira é óbvio que só uma ação concertada de um numeroso conjunto de países poderia constituir uma base - à maneira da que o navegador concebeu para o seu ovo - capaz de opor-se à política neoliberal da UE (muitos terão pensado nesta atitude, mas só através de um golpe de intuição inesperado foi possível pô-la em prática, em face da pertinaz e perversa oposição das instituições europeias não eleitas, que fazem o papel da força gravítica que levava o ovo a rebolar, quando este se mantinha como um esferoide intacto). Este golpe de intuição teve condições para se déclancher em Berlim, a partir de uma iniciativa de Yanis Varoufakis a 9 de fevereiro de 2016, batizada DiEM25 (Democracy In Europe Movement 2025).

\section{DiEM25 (Democracy in Europe Movement 2025)}

\section{Lançamento}

O manifesto de lançamento do DiEM25 abarcou as causas específicas de um movimento de esquerda, cosmopolita, internacionalista e transeuropeu, pensado no sentido de favorecer os $99 \%$ onde se incluem os subalternos (SPIVAK, 2010) de que já falava Gramsci nos seus cadernos de prisão. Os principais pontos do manifesto, subscrito por gente tão diversa (e respeitada) como Yanis Varoufakis, Brian Eno, James Galbraith, Ken Loach, Slavoj Zizek, Boaventura Sousa Santos..., encontram-se em www.diem25.org.

Se o anúncio desta iniciativa mereceu algumas linhas na imprensa internacional (na convicção de que era mais um 'abaixo-assinado' sem qualquer efeito político, para além de dar - maior - visibilidade a alguns nomes já sonoros), o que é fato é que o mais completo silêncio se abateu sobre o primeiro ato concreto de consolidação prática das ideias afloradas em Berlim, através de um Seminário/Meeting realizado em Madrid em 19/21 de Fevereiro de 2016, no MATADERO (antigo açougue a uma escala gigantesca, hoje transformado num espaço cultural) com a presença (discreta) de Varoufakis, M. Albiol (eurodeputada do Podemos), F. Louçã, e de mais uma centena de participantes.

Plan B - Madrid, 19-21 de fevereiro de 2016

Neste Seminário/meeting, teve lugar uma série de 24 assembleias e workshops, cujo trabalho consistiu em lançar bottom up as bases de um PLANO B para a Europa, centrado na

\section{POLÊM!CA $\mid$ LABORE}


reestruturação da dívida ("no debemos, no pagamos") e do sistema financeiro, contemplando institucionalmente os mais desfavorecidos (incluindo, obviamente, os migrantes).

Na sessão de encerramento, o coordenador de cada tópico transmitiu as conclusões dos trabalhos e propostas de ação, de que se dão alguns exemplos seguidamente:

1. Reforzar y ampliar la red de movimientos europeos contra la deudocracia y la austeridad.

2. Compartir las experiencias de los procesos de auditoría ciudadana, lucha contra la deudocracia y la austeridad.

3. Aprovechar el conocimiento de activistas y expertas cercanas a los movimientos sociales para profundizar en nuestras propuestas y promover acciones de formación de formadores.

4. Promover espacios de confluencia entre movimientos sociales, técnicos y grupos políticos para compartir metodologías y experiencias en realización de auditorías ciudadanas. En este sentido el primero de dichos encuentros será en Barcelona en octubre de 2016.

5. Construir un nuevo discurso alrededor de la deudocracia, que ayude a colocarla en el centro de la agenda y situé el impago de la deuda ilegítima como estrategia posible. 6. Elaborar materiales de formación, metodológicos y comunicativos, compartirlos y difundirlos a nivel europeo.

A sessão de encerramento decorreu perante uma multidão (da ordem dos milhares de pessoas) aglomerada junto ao rio Manzanares de triste/alegre memória - porque os franquistas o ultrapassaram, apesar da heroica resistência das Brigadas Internacionais (BI). Este episódio, imortalizado nas "Coplas de la defensa de Madrid", foi de resto evocado por Varoufakis, ao sugerir que o novo movimento transeuropeu tinha algo em comum com as BI, renascidas das cinzas no contexto da nossa época sob o lema "carpe diem" (um détournement da própria sigla do movimento), que pode ser visto como 'fazer a festa', perdendo o mínimo de tempo com coisas inúteis (por exemplo, as tricas entre os partidos de cada estado-nação).

Apresenta-se na Fig. 5 uma montagem representando esta atividade e o seu entorno.

Figura - 5: O encontro PLAN B de DiEM25 (19-21 de fevereiro de 2016) e o seu entorno

\footnotetext{
${ }^{4}$ Puente de los franceses, puente de los franceses, puente de los franceses, mamita mía, nadie te pasa, nadie te pasa. / Porque los milicianos, porque los milicianos, porque los milicianos, mamita mía, qué bien te guardan, qué bien te guardan. / Por la Casa de Campo, por la Casa de Campo, por la Casa de Campo, mamita mía, y el. Manzanares, y el Manzanares / Quieren pasar los moros, quieren pasar los moros, quieren pasar los moros, mamita mía, no pasa nadie, no pasa nadie. / Madrid qué bien resiste, Madrid qué bien resiste, Madrid qué bien resiste, mamita mía, los bombardeos, los bombardeos. / De las bombas se ríen, de las bombas se ríen, de las bombas se ríen, mamita mía, los madrileños, los madrileños...
}

\section{POLÊM!CA $\mid$ LABORE}

Polêmica - Revista Eletrônica da Uerj - Rua São Francisco Xavier, 524, $1^{\circ}$ andar

bloco D, sl.1001 • Tels.: +55 21 2334-4088/4087 • http://www.e-publicacoes.uerj.br/index.php/polemica/index http://www.labore.uerj.br • laboreuerj@yahoo.com.br 


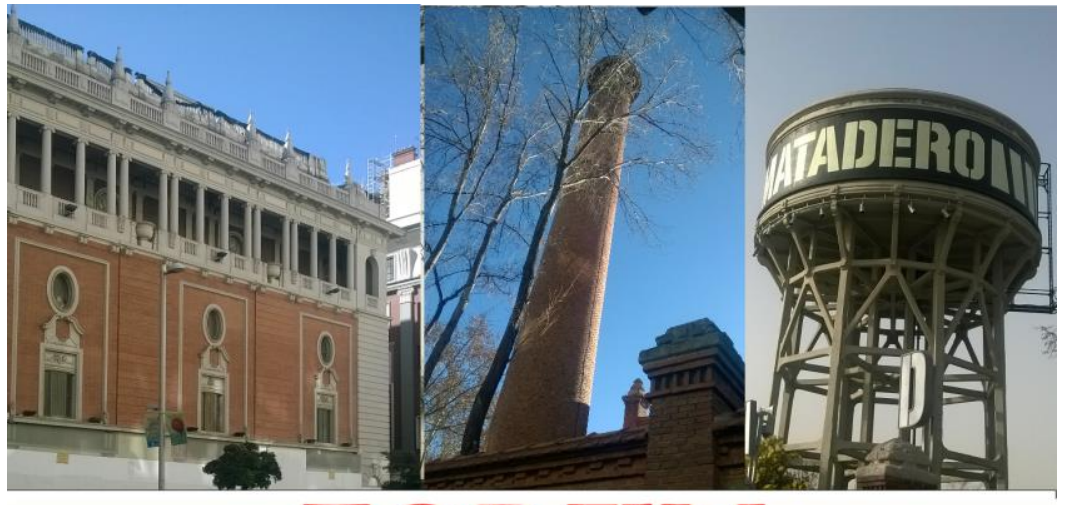

FORUM
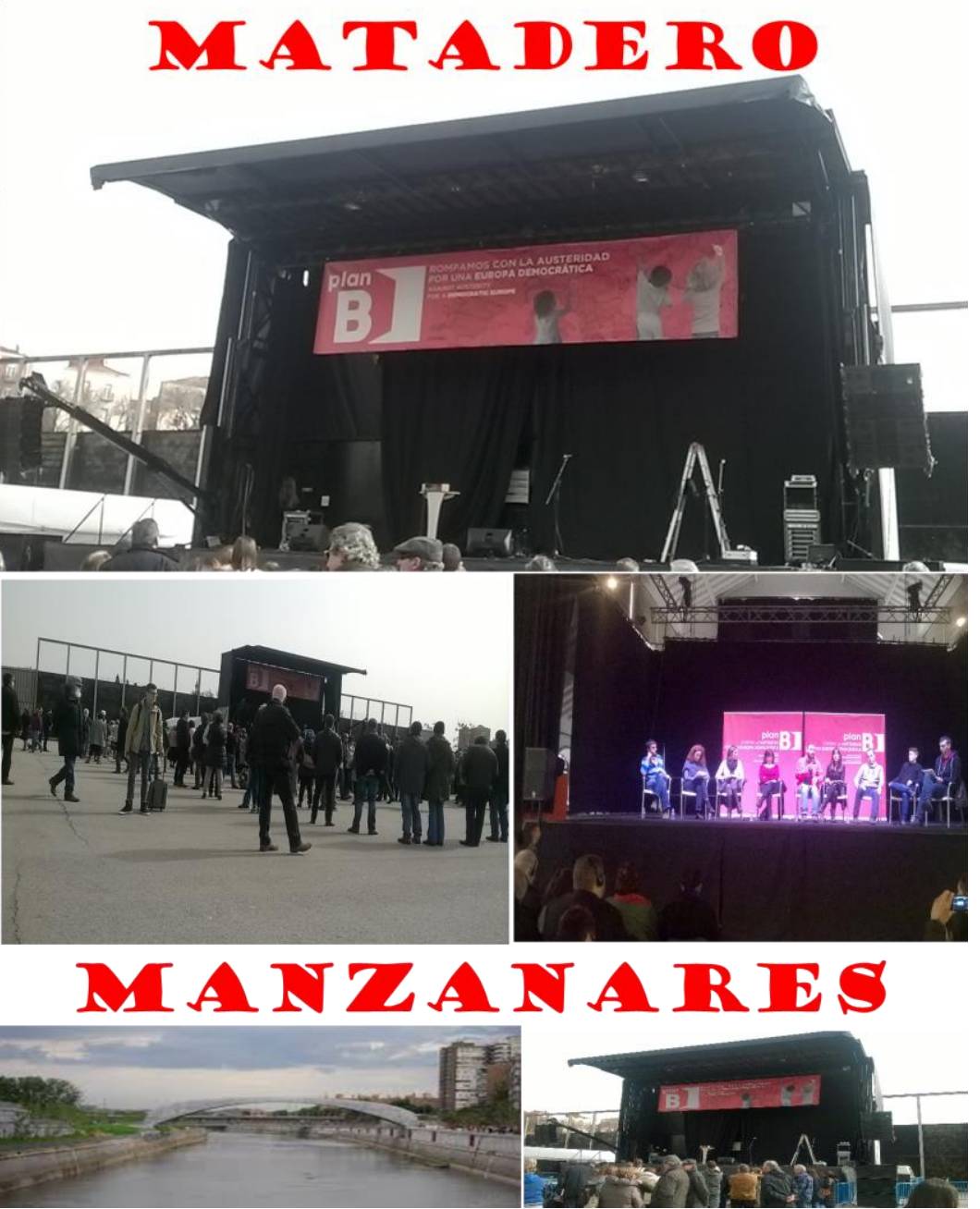

Fonte: Montagem de fotos do autor.

De Paris ("NUIT DEBOUT, 31 de março de 2016) a Viena (5 de maio de 2016)

Em sintonia com uma manif sindical contra a "lei do trabalho" de François Hollande/Manuel Valls ('socialistas' que pugnam pela 'flexibilização laboral' imposta pela

\section{POLÊM!CA $\mid$ LABORE (}

Polêmica - Revista Eletrônica da Uerj - Rua São Francisco Xavier, 524, $1^{\circ}$ andar bloco D, sl.1001 • Tels.: +55 21 2334-4088/4087 • http://www.e-publicacoes.uerj.br/index.php/polemica/index http://www.labore.uerj.br • laboreuerj@yahoo.com.br 
UE), o DiEM25 integrou a grande concentração de 31 de março, na République (Fig. 6), em que os manifestantes acabaram por ocupar a praça, num acampamento do tipo dos que se iniciaram em Madrid, há 5 anos (15M, na Puerta del Sol).

Figura - 6: Nuit Debout, na République (31 de março de 2016)

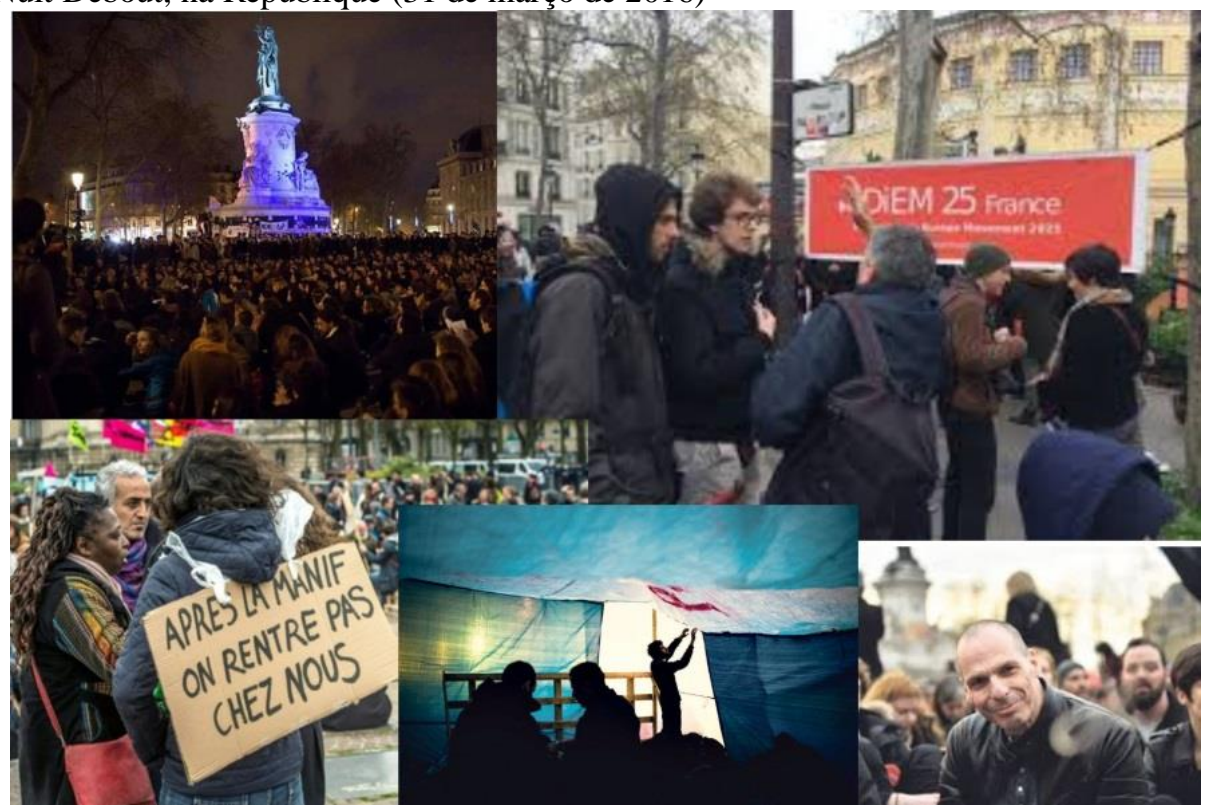

Fonte: Colagem de fotos do "Libération" (abril 2016).

Durante os meses subsequentes ao 31 de Março (e até, pelo menos, 31 de Maio), a République tornou-se o centro do Paris revolucionário deste milénio, com concentrações (quase) permanentes de um amplo espetro de insurretos inter-geracionais (Fig. 7), interventores nos conflitos com os CRS, um pouco à maneira de Mai68 (Fig.8).

\section{POLÊM!CA $\mid$ LABORE (: (:)}


Figura - 7: Queremos tudo, e já

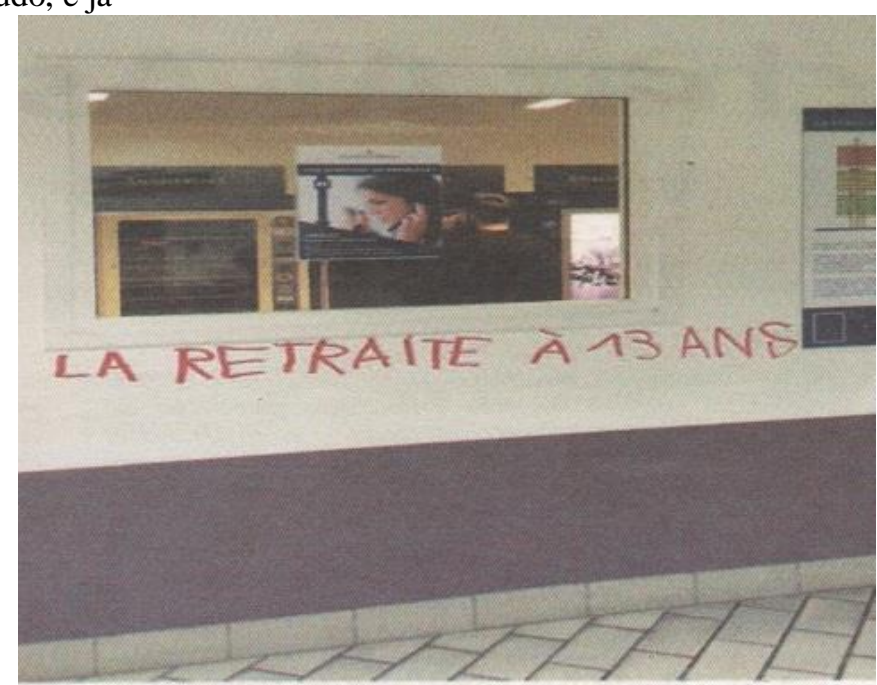

Fonte: "Monde Diplomatique", abril 2006.

Figura - 8: os CRS de Mai68 revisitam a République de Mars16
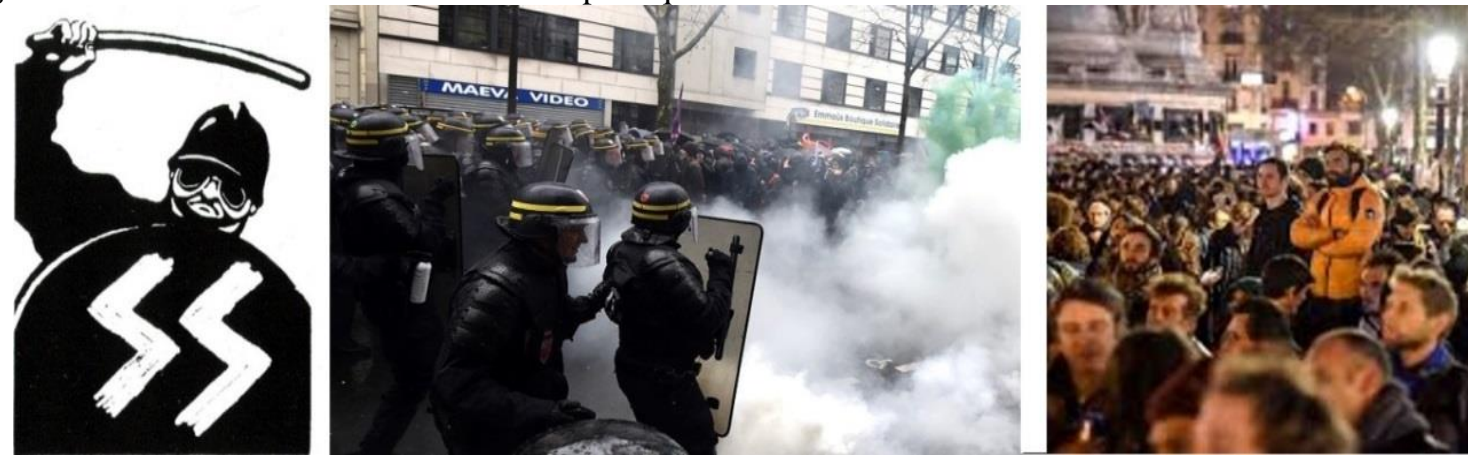

Fonte: Composição do autor.

Transcrevem-se nas linhas seguintes extratos de um 'discurso' que exprime de um modo magnífico a experiência da deriva pelo acampamento da République, por parte de alguém que não podia ter estado nas barricadas de maio de $68^{5}$, mas que apanhou o seu flavour por fontes indiretas (ZECHER, 2016):

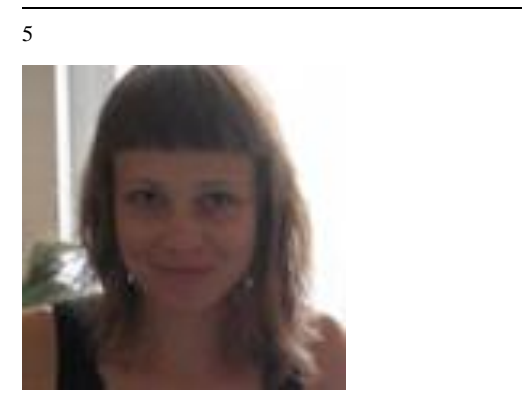

\section{POLÊM!CA $\mid$ LABORE (3)}

Polêmica - Revista Eletrônica da Uerj - Rua São Francisco Xavier, 524, $1^{\circ}$ andar bloco D, sl.1001 • Tels.: +55 21 2334-4088/4087 • http://www.e-publicacoes.uerj.br/index.php/polemica/index http://www.labore.uerj.br • laboreuerj@yahoo.com.br 
(...) That day Nuit Debout's international working group organized assemblies and action planning on the Place de la République in Paris. Some hundred people came from all over Europe and beyond to get to know this new movement in one of the heartlands of the European crisis (...) Suddenly the clock struck 6pm and silently, almost imperceptibly at first, bodies began to flow in and gently fill the vast Place. Tents went up, people helping each other and chatting, and tables with radio equipment, coffee and tea, flyers and books, lots of small sound systems around which people started to gather in circles. Before I knew it, the square was pulsating with political debates and encounters, a vast array of thematic and practical endeavors, hundreds of people sitting, standing, watching, moving around or passing by. Their faces open, listening, interested and exposed. When you move in an open space of anonymous sociality, in a space radically open to conversation between strangers, your body takes on a certain posture and attitude, of intense attention and relaxed friendliness at the same time. My body had forgotten a lot of things; sitting on the dirty concrete of a public square, for example. Our bodies - I daresay not just mine - were reactivated with a certain memory, of relationality and affect. It's those embodied memories that are the most powerful for creating collective ways of being together, forms of subjectivity that come to last because they build on shared new habits in space.

O relato cintilante acima reproduzido (e o seu intertexto) é a expressão (quase) literal da cidade, e - em particular - da 'praça', formalizada(s) como TEXTO à maneira de Gastal (2006), na esteira (completamente) literal $^{6}$ de Darnton (1989) e (mais esfumada) de Le Goffe, Lefébvre, Barthes... Este texto faz da 'praça' o locus de um sentido específico, o sentido que explode a partir da atitude revolucionária "das gentes vindas de toda a Europa (and beyond)". A esta atitude, Gastal (2006, p. 70), chama cosmopolidade, ou seja, (cosmopolitismo + diversidade). A praça torna-se assim, nos momentos de exaltação subversiva, um significante que só tem significado quando ocupada pelo 'flow' de manifestantes. É de notar que este renascimento da praça é característica da pós-crise de 2011. De fato, depois do auge da IdadeMédia, a modernidade e a pós-modernidade tinham subvalorizado um pouco este fixo (substantivo alegórico da praça, como o vértice de um grafo), feito de alguns elementos que o texto aqui comentado tão bem espelha: estrutura lúdica, togetherness, convivialidade, intimacy with strangers, e memória 'corporal'. No texto, perpassa também um certo individualismo à la Negri, temperado pela indispensável auto-organização que caracteriza a nova forma de protesto que consiste em ocupar durante um certo lapso de tempo as praças de (quase) todas as cidades do mundo.

\footnotetext{
${ }^{6}$ Assim como, hoje em dia, o lúmpen das banlieues deita fogo aos automóveis, num gesto de revolta pura, Darnton (1989) 'dá conta' de uma ação revolucionária onde surge, pela primeira vez, a correspondência textocidade: Em 1730 os oprimidos do Ancien Régime perpetraram o 'massacre de todos os gatos' pertencentes aos burgueses do seu quartier (será que o automóvel pode ser visto como o sucedâneo - ou talvez como um simples suplemento - de algum 'animal de estimação'?).
}

\section{POLÊM!CA $\mid$ LABORE}

Polêmica - Revista Eletrônica da Uerj - Rua São Francisco Xavier, 524, $1^{\circ}$ andar

bloco D, sl.1001 • Tels.: +55 21 2334-4088/4087 • http://www.e-publicacoes.uerj.br/index.php/polemica/index http://www.labore.uerj.br • laboreuerj@yahoo.com.br 
Comme d'habitude, o mais completo silêncio abateu-se inicialmente sobre as manifs que levavam à République (e de outras praças de cidades francesas, como Nantes, Rennes, Bordéus, Lyon...), por parte dos 'jornais de referência', exceto talvez no caso em que houve afrontamentos com a polícia (para assustar “les braves gens”, como cantava o Brassens). Surpreendentemente, a iniciativa da République tornou-se uma espécie de centelha que inflamou o país. De fato, "Le Monde" dava conta (na primeira página de 26.05.2016) da greve (quase) geral que afetou os transportes aéreos, o abastecimento de combustível para a sacrossanta bagnole que os franceses idolatram, e até a disponibilidade em outras formas de energia dependentes do 'intocável' nuclear.

Parece assim que, finalmente, "a França entrou na dança” (dos ritmos latinos).

Passando agora ao encontro de Viena, a 5 de maio de 2016, surge no âmbito do DiEM25 - não pela primeira vez, mas desta vez de um modo intempestivamente prioritário o 'problema dos refugiados' (Fig. 9).

Figura - 9: O DiEM25 e o problema dos refugiados

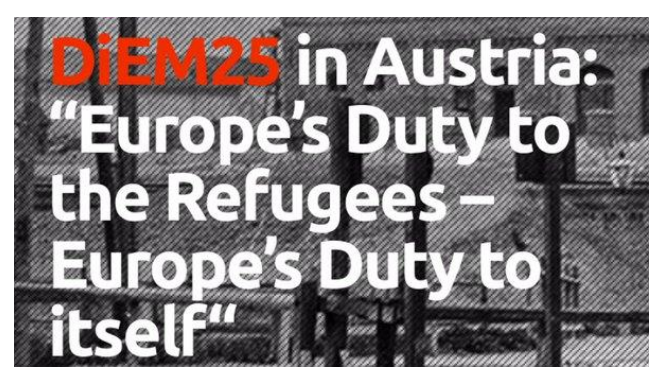

Fonte: DiEM25.

\section{O Problema dos refugiados/migrantes na Europa}

Só em 2015, chegaram à Europa, pela rota do mediterrâneo, mais de um milhão de pessoas (MATIAS, 2016), dando visibilidade à chamada "crise dos refugiados" (tema este amplamente desenvolvido na mídia ${ }^{7}$, ao contrário dos que foram aqui anteriormente aflorados).

\footnotetext{
${ }^{7}$ Para além da amplidão do movimento (o que o torna difícil de 'esconder'), os poderes que controlam a difusão da informação para o 'público' vêem alguma vantagem na visibilidade deste fenómeno: desencadeiam no subalterno o medo do 'outro', daquele que - pretensamente - poderá vir a tomar o seu lugar (e ameaçar a sua civilização com hábitos 'estranhos', que podem ser físicos - por exemplo, a burka -, e simbólicos, da ordem dos ritos religiosos). Também o fantasma do terrorismo (que o establishment associa a todo o refugiado/migrante) tem sido profusamente explorado, carregado de ameaças ancestrais que - supostamente - tendem a provocar um medo irracional nos burgueses 'lepidópteros' (irónica denominação aplicada, nos anos 30 do século XX, aos
}

\section{POLÊM!CA $\mid$ LABORE}

Polêmica - Revista Eletrônica da Uerj - Rua São Francisco Xavier, 524, $1^{\circ}$ andar

bloco D, sl.1001 • Tels.: +55 21 2334-4088 / 4087 • http://www.e-publicacoes.uerj.br/index.php/polemica/index http://www.labore.uerj.br • laboreuerj@yahoo.com.br 
Esta é uma pendência que tomou a configuração atual há cerca de uma década, com um claro recrudescimento a partir de 2011 (início da crise financeira). Uma "coincidência" deste calibre permitir-nos-á porventura ligar o problema dos refugiados empurrados pelos conflitos agónicos ao dos migrantes económicos (empurrados pela fome e pela miséria), já que um germe comum surge nos dois fenómenos: o estouro do capitalismo financeiro, com duas vertentes simultâneas: por um lado, a aceleração vertiginosa das guerras punitivas desencadeadas - sobretudo no Médio Oriente - pelos mercadores de armas (em "crise" de sobreprodução), e por outro, a sobredepleção dos recursos naturais (e outros mais efémeros) pertencentes aos países menos desenvolvidos, por parte das grandes empresas multinacionais (em “crise" de expansão).

Em suma, na raiz dos efeitos desastrosos provocados pelas duas faces da mesma moeda (refugiados/migrantes) estão obviamente "os suspeitos do costume", como diz com alguma acidez jocosa Zizek (2016).

Mas vejamos alguns aspetos que dão conta da maior crise humanitária que assolou a Europa nos últimos anos a uma escala verdadeiramente descomunal, e de algumas particularidades (facilmente generalizáveis) do modo como a UE e outras instâncias ocidentais (não) têm encarado a questão, tentando sempre escusar-se às suas responsabilidades (a tal duty to itself evocada na Fig. 9).

Transportados como gado pelas mafias das mais diferentes origens em frágeis embarcações (Fig. 10A), a massa babilónica dos refugiados/migrantes que escapa aos naufrágios (Fig. 10B) inicia em terra um percurso titubeante (Fig. 10C) - através do espaço estriado (à la Deleuze) por uma panóplia de obstáculos de genealogia nacionalista (Fig. 10D,E) - que os leva a verdadeiros campos de concentração improvisados (Fig. 10F).

Esses campos, onde se espera pelo nada e onde não há nada a esperar, são piores do que Guantánamo, segundo o testemunho do prisioneiro Mohammed Bwazir, transmitido a um jornalista de EL PAÍS (Fig. 11).

Figura - 10: A rota dos refugiados/migrantes

reacionários culturais desse tempo, por parte de Fernando Pessoa e Mário de Sá Carneiro, no âmbito do modernismo português representado pela revista ORFEU).

\section{POLÊM!CA $\mid$ LABORE.}




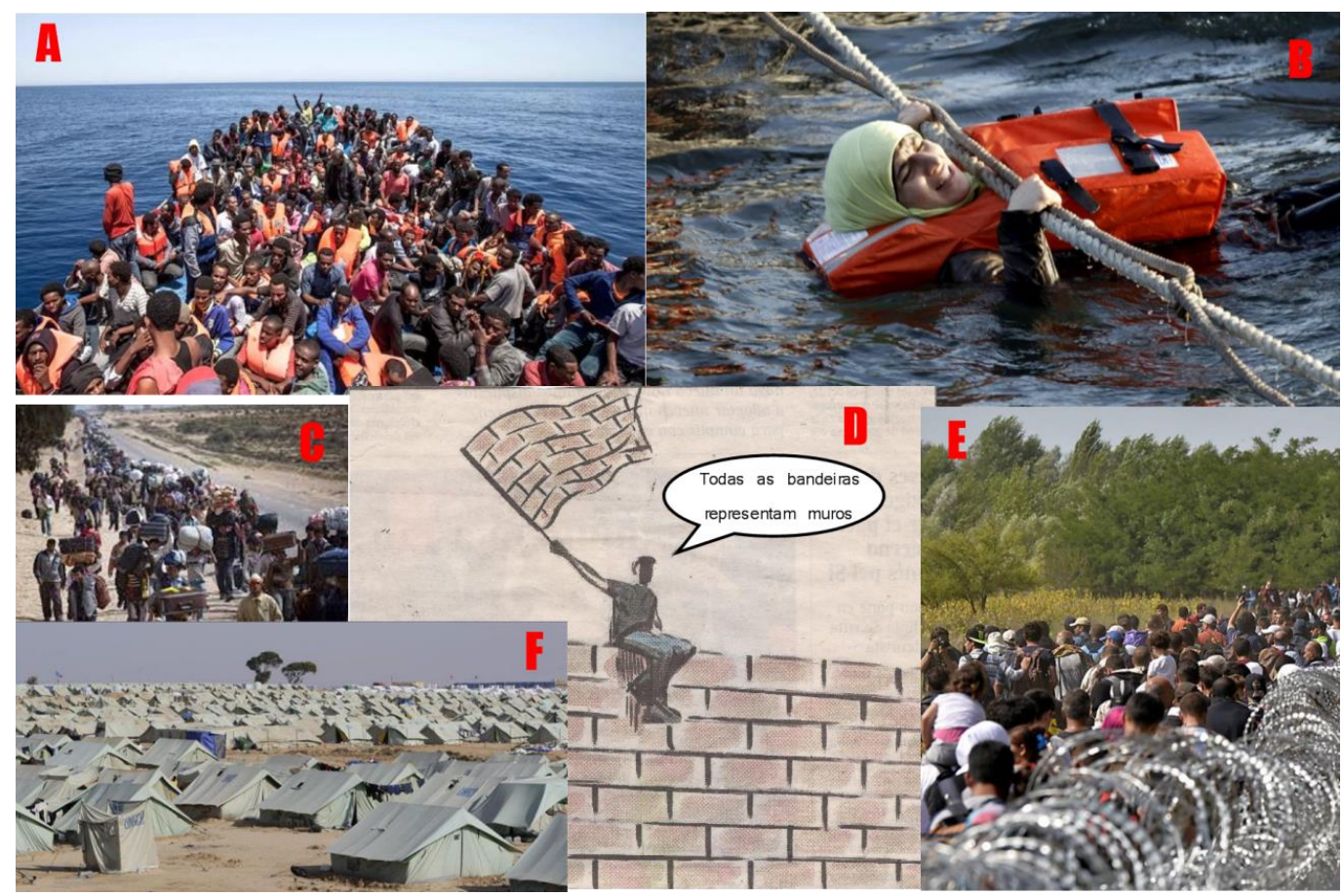

Fonte: Sequência de imagens articuladas pelo autor.

Figura - 11: Os campos de refugiados/migrantes europeus comparados com uma prisão de alta segurança administrada pelos Estados Unidos em Cuba

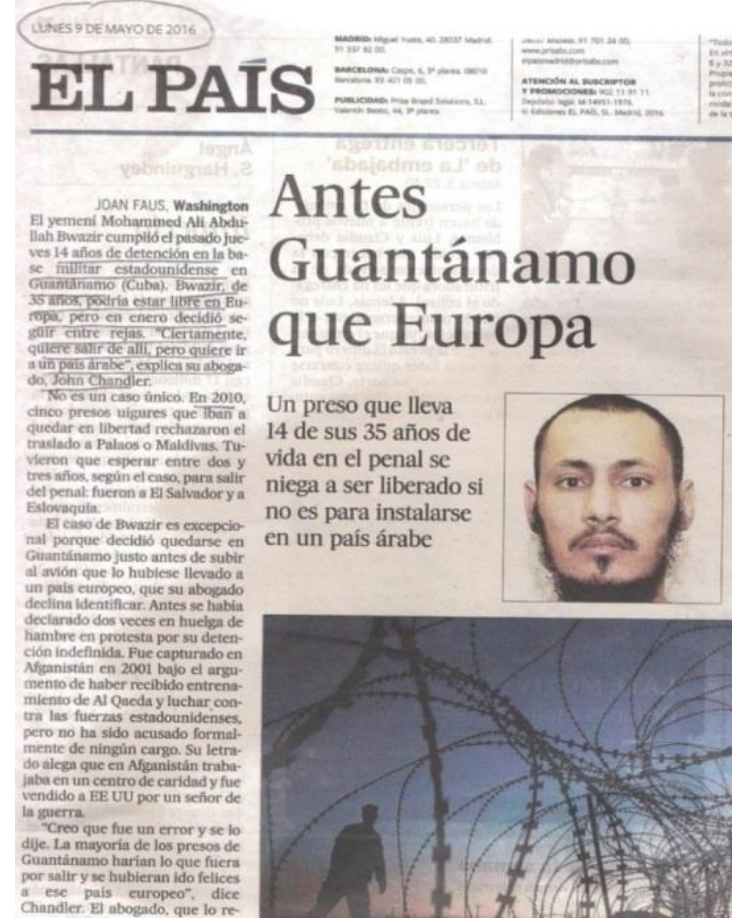

Fonte: El PAÍS, 9 de Maio de 2016.

Pela opinião que a notícia da Fig. 11 deixa transparecer (como mero exemplo), pode ter-se uma (pálida) ideia da inqualificável pauta de sevícias vexatórias a que são submetidos

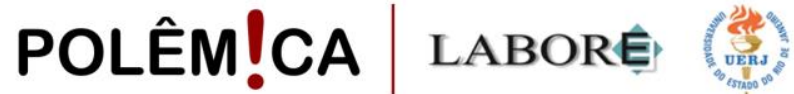

Polêmica - Revista Eletrônica da Uerj - Rua São Francisco Xavier, 524, $1^{\circ}$ andar bloco D, sl.1001 • Tels.: +55 21 2334-4088/4087 • http://www.e-publicacoes.uerj.br/index.php/polemica/index http://www.labore.uerj.br • laboreuerj@yahoo.com.br 
os refugiados/migrantes, tanto ao longo do seu itinerário errático ${ }^{8}$ pela Europa amuralhada, como nos campos de internamento do tipo nazi, onde também o 'outro' - judeu, comunista, homossexual, cigano... - era espezinhado pelos agentes da "banalidade do mal", como diria Hannah Arendt. Este paralelismo, que "desafia o pensamento", não pode deixar de ser evocado quando assistimos às "ordens" (à maneira das que Eichmann invocou em tribunal) a que obedecem os decisores alemães que comandam a UE. Assim, a chanceler Merkel, depois de declarar inicialmente que o seu país estava pronto a receber uma quota considerável de fugitivos, cedo (em meados de maio de 2016) se prontificou a obedecer a ininteligíveis “ordens" para fechar a fronteira alemã aos refugiados ( $v d$. Fig. 12) que sobreviviam à "rota dos Balcãs', cedendo talvez à pressão maléfica da CSU, (União Social Cristã, partido indispensável à coligação no poder). Por fim, o governo alemão cedeu em receber a sua quota de refugiados, desde que esta contemplasse apenas sobreviventes das guerras do Médio Oriente que se revelassem cumpridores escrupulosos de um "programa de integração" topdown baseado no inefável "conhecimento da língua" e na atribuição de um qualquer Arbeit, que continua a macht frei (como em Dachau).

Figura - 12: Fecho da fronteira alemã em maio de 2016, sob as "ordens" balouçantes de Merkel

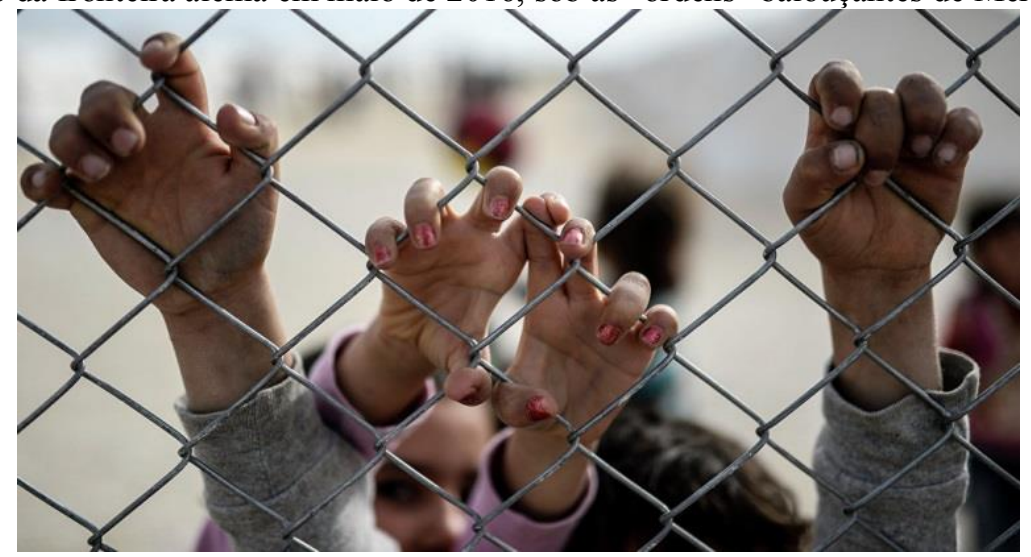

Fonte: AFP 2016/ BULENT KLIK.

E até os 'impolutos' CAPACETES AZÚIS da ONU (os "soldados da paz") beneficiaram - durante cinco anos - de um cambalache envolvendo a alimentação destinada

\footnotetext{
${ }^{8}$ Que faz irresistivelmente lembrar o vagabundear do Flying Dutchman, no campo da lenda, e - no campo da realidade - o movimento aleatório das hordas dos sem-terra e sem-teto que percorrem (ainda?) o Nordeste Brasileiro.
}

\section{POLÊM!CA $\mid$ LABORE}


aos mais desventurados (e esfomeados) foragidos do Líbano, que era vendida a peso de ouro aos comerciantes locais (EL PAÍS, 25.05.2016).

Como seria de esperar (pela voz sofrida de Hannah Arendt), o padrão que se encontra no exemplo anterior repete-se em (pelo menos) dois domínios (conexos): a mercantilização da "ajuda aos refugiados" por parte de algumas ONGs, em que surge o oximóron da solidariedade remunerada (Fig. 13), e a intervenção - sempre omnipresente para tornar a desgraça ainda mais desgraçada - da caridadezinha de raiz cristã dirigida às crianças sob o lema “fatos, não palavras" (Fig. 14).

Figura - 13: Modelo de mercantilização da solidariedade

\section{ECA, España con ACNUR Captador de socios ONG Madrid}

Trabaja con nosotros media jornada con un sueldo fijo de 800 euros brutos al mes más incentivos y contratación directa por EACNUR, como promotor/captador de socios, dentro del programa Face to Face.

Si quieres empezar a trabajar en una ONG, en EACNUR buscamos gente extrovertida, dinámica y con afán de superación, comprometida con los valores de ACNUR e interesada en la ayuda humanitaria y la labor social, para trabajar como promotor/captador, ayudándonos en la tarea de sensibilización y captación de fondos que llevamos a cabo en calles transitadas, centros comerciales, estaciones...

La tarea del promotor/captador de socios consiste en informar a la gente sobre el trabajo en terreno de ACNUR y animarles a colaborar con nosotros, ya que esto es imprescindible para poder financiar nuestros proyectos.

No es necesario tener experiencia previa como promotor/captador de socios para ONG.

Ofrecemos:

- Sueldo base de 800 euros brutos al mes más incentivos.

- Media jornada, 4,5 horas diarias en turno de mañana o tarde, de lunes a viernes (22,5 horas semanales).

- Contratación directa por EACNUR, sin intermediarios; alta en la SS (no autónomos, no mercantil).

- Formación continua a cargo de la organización, incluyendo cursos externos.

- Posibilidad de promoción.

- Horarios flexibles (prácticas, exámenes, etc.).

- Campañas de verano, viajes de empresa, movilidad geográfica por cambio de domicilio y posibilidades de viajar a terreno.

Para acceder a la oferta de trabajo introduce el JOB ID: 159138399 en el buscador de empleo.elpais.com

Fonte: Anúncio em “EL PAÍS”, 23 de maio de 2016.

Figura - 14: Tornar a desgraça ainda mais desgraçada, entregando-a à publicidade

\section{POLÊM!CA LABORE (:}

Polêmica - Revista Eletrônica da Uerj - Rua São Francisco Xavier, 524, $1^{\circ}$ andar bloco D, sl.1001 • Tels.: +55 21 2334-4088/4087 • http://www.e-publicacoes.uerj.br/index.php/polemica/index http://www.labore.uerj.br • laboreuerj@yahoo.com.br 


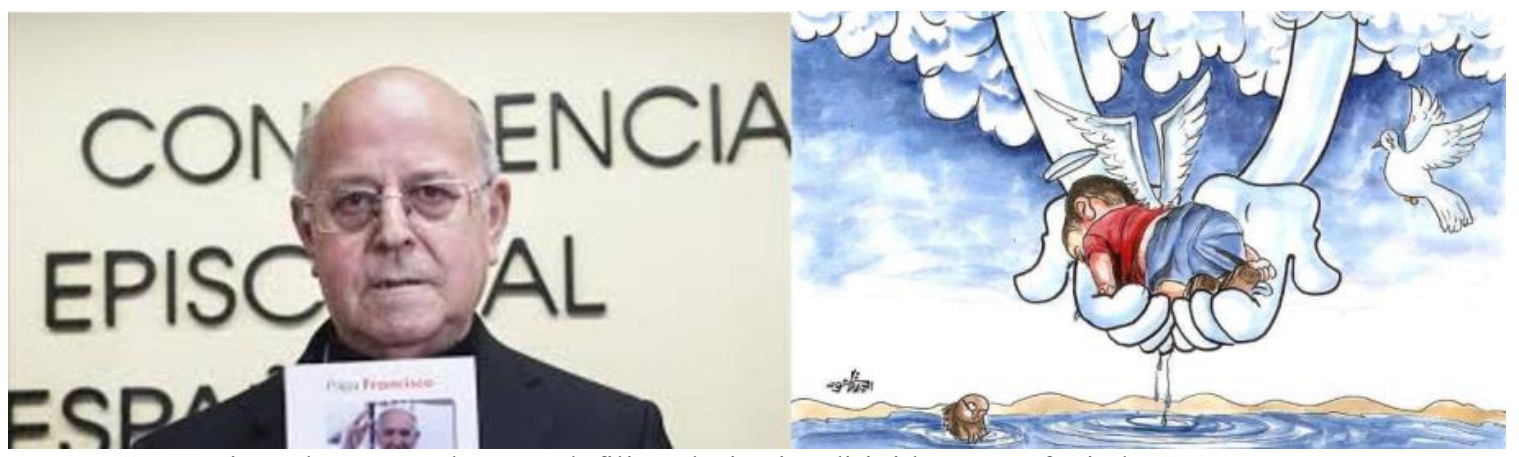

Fonte: Composição do autor sobre a pedofilia eclesiástica dirigida aos "refugiados".

Do ponto de vista "ideológico", a xenofobia nacionalista que quer "preservar o seu modo de vida" $" 9$ ataca em todas as frentes, a começar pela questão básica da recusa por parte da maioria dos países do Norte em receber a sua "quota de refugiados", estabelecida pelas mais altas instâncias da UE (que a "esses costumes disseram nada", empenhando-se em castigar os países do Sul, apesar destes se apresentarem de braços abertos para receber o 'outro', numa ética de hospitalidade quase generalizada).

Obviamente que o DiEM25 luta com o maior vigor pelo acolhimento dos refugiados/migrantes de igual para igual, condenando toda a discriminação dos homens e mulheres que chegam à Europa por razões económicas ${ }^{10}$, e o repatriamento para a Turquia (Custo $=3 \times 10^{9}$ euro) das vítimas que fogem às guerras desencadeadas pelo capitalismo financeiro (Fig. 15).

Figura - 15: Contra a mercantilização dos fluxos de refugiados entre a EU e a Turquia

\footnotetext{
${ }^{9}$ É de notar - com Zizek (2016, p. 25) - que as "alterações económicas" desencadeadas pela crise financeira de 2011 fizeram mais para destruir o (pretensamente ancestral) modo de vida europeu do que todos os imigrantes juntos!

${ }_{10}$ Zizek (2016, p. 60) evoca Conrad e o "coração das trevas" congolês, onde 4 milhões de pessoas teriam morrido na última década em resultado da violência fomentada pelas multinacionais, estabelecendo uma analogia gritante (e comovente) com a "questão dos refugiados" (como é entendida pela UE).
}

\section{POLÊM!CA $\mid$ LABORE (}




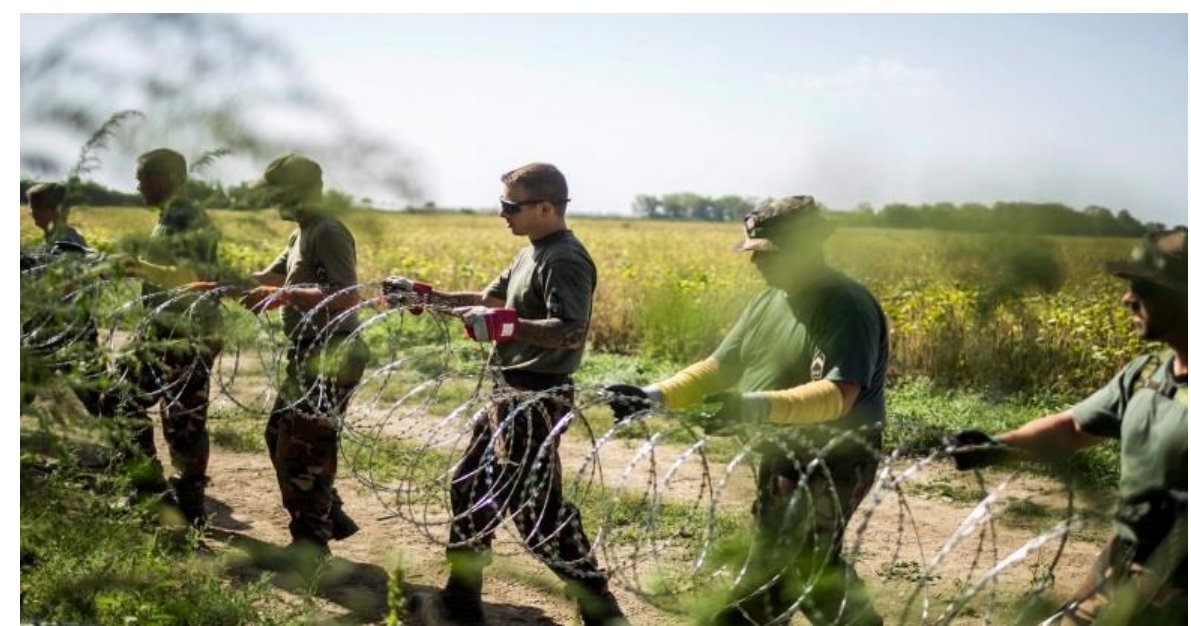

Fonte: Press Statement: Condemning European Summit's Preliminary Accord to Expel Refugees to Turkey.

De resto, Yanis Varoufakis, como porta-voz ad hoc do DIEM25, elogia a "resposta magnífica dos gregos ao problema dos refugiados" numa entrevista ao Channel 4 britânico, chamando a atenção para o verdadeiro símbolo de hospitalidade universal representado na Fig. 16 (e que contrasta com a indiferença idiota ${ }^{11}$ de alguns habitantes dos países do Norte, disciplinados pelo mal absoluto).

Figura - 16: Símbolo de uma hospitalidade universal e cosmopolita aplicada aos não- alienígenas, desreguladora das imposições do mal absoluto

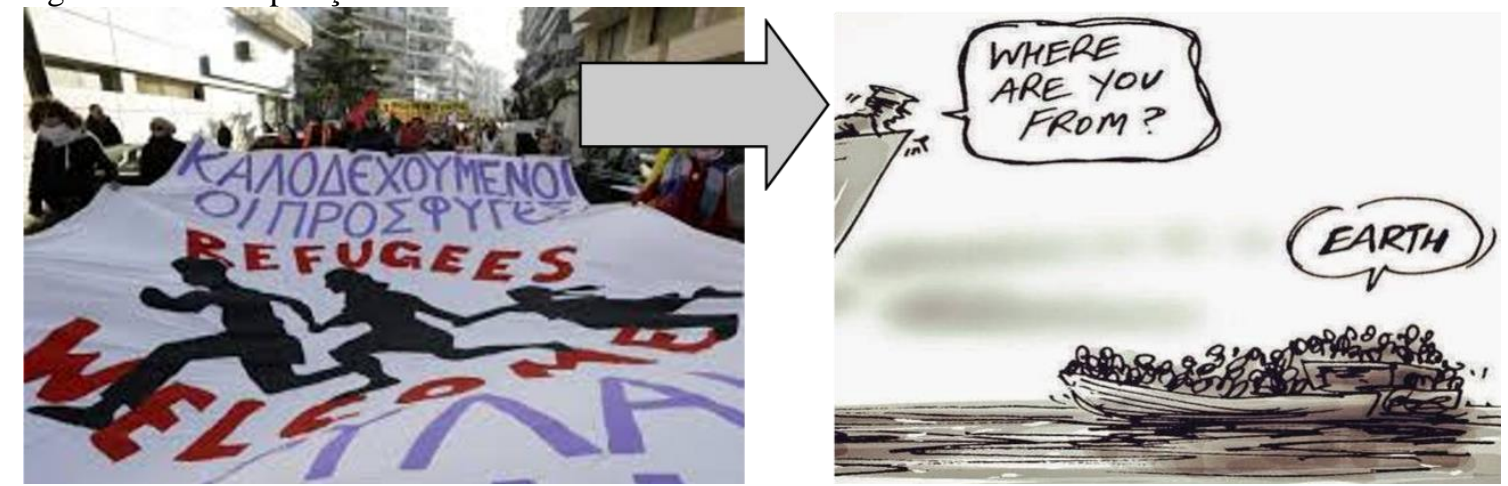

Fonte: DiEM25.

Na verdade, a Grécia - que é a mais importante "porta de entrada" na Europa (vd. Fig. 17) - encara com a maior sensibilidade e afeição a torrente de refugiados/migrantes que chegam aos milhares às suas costas e ilhas. Por exemplo, na Fig. 18 pode apreciar-se a

\footnotetext{
${ }^{11} \mathrm{Na}$ Grécia clássica, o ideotés era aquele que não participava nos assuntos públicos, preferindo dedicar todo o seu tempo à vidinha (como diria O’Neill, 2012, poeta português de feição surrealista dos meados do século 20). Péricles - num flash forward impressionante que anunciava o nosso bardo anticonformista - deplorava que houvesse em Atenas tantos homens livres indiferentes - idiotas - que não se preocupavam com as questões da polis, fechando-se no seu mundo feito de regras indiscutíveis.
}

\section{POLÊM!CA $\mid$ LABORE (}

Polêmica - Revista Eletrônica da Uerj - Rua São Francisco Xavier, 524, $1^{\circ}$ andar bloco D, sl.1001 • Tels.: +55 21 2334-4088/4087 • http://www.e-publicacoes.uerj.br/index.php/polemica/index http://www.labore.uerj.br • laboreuerj@yahoo.com.br 
amálgama de gente de todas as origens que afluem à principal praça de Atenas, num exercício de inteligência coletiva sem limites.

Figura - 17: Acréscimo nas chegadas à Grécia de Refugiados/migrantes (2014-2015)

\begin{tabular}{l} 
ARRIVALS of Refugees and Migrants \\
in Greece \\
\hline
\end{tabular}

Fonte: United Nations Refugee Agency.

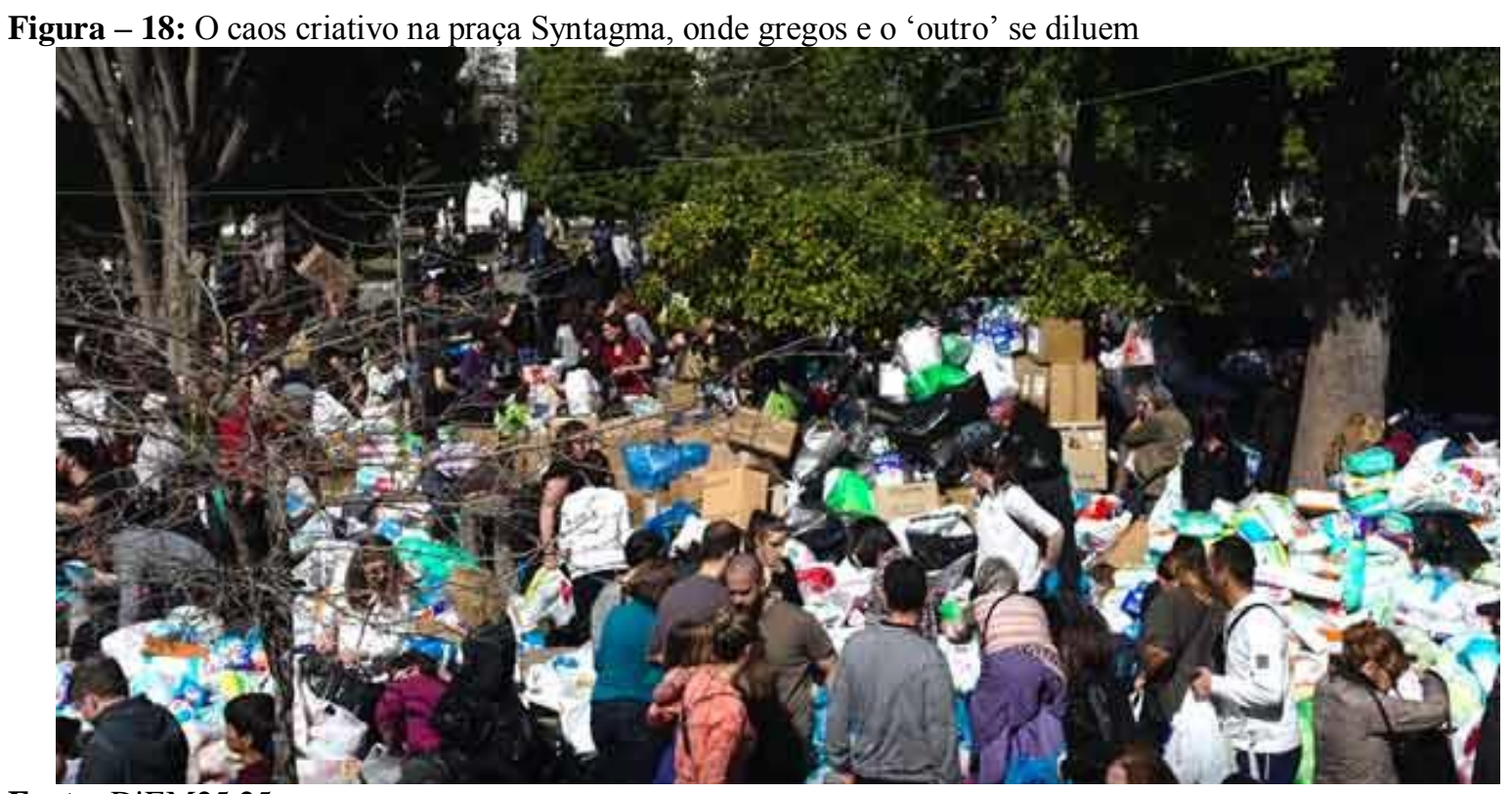

Fonte: DiEM25 25.

\section{POLÊM!CA | LABORÊ, (t)}

Polêmica - Revista Eletrônica da Uerj - Rua São Francisco Xavier, 524, $1^{\circ}$ andar bloco D, sl.1001 • Tels.: +55 21 2334-4088/4087 • http://www.e-publicacoes.uerj.br/index.php/polemica/index http://www.labore.uerj.br • laboreuerj@yahoo.com.br 
Em jeito de 'não-conclusão', e a propósito dos refugiados/migrantes, poderá dizer-se parafraseando Adorno - que a tarefa mais difícil é não se deixar atordoar, tanto pelo poder dos outros como pela impotência própria.

\section{Referências}

ALMEIDA, M.V. Um mar da cor da terra, Raça, Cultura e Política da Identidade. Lisboa: Celta, 2000.

DARNTON, R. O grande massacre de gatos: e outros episódios da história cultural francesa. São Paulo: Companhia das Letras, 1989.

GASTAL, S. Alegorias Urbanas. O Passado como Subterfúgio. São Paulo: Papirus, 2006.

LACLAU, E.; MOUFFE, C. Hegemony and socialist strategy: Towards a radical democratic politics. London: Verso, 2013.

MATIAS, G.S. O desafio e a oportunidade da integração, XXI TER OPINIÃO, p. 96, jan-jun. 2016.

MONEDERO, J.C. Curso urgente de política para gente decente. Barcelona: Planeta, 2013.

O’NEILL, A. Poesia Completa. Lisboa: Assírio \& Alvim, 2012.

PEREIRA, H.G. Fragmentos do Mediterrâneo. Vol. 1 - O rendilhado Oriental. Lisboa: Teorema, 2008.

SPIVAC, G. Pode o subalterno falar? Belo Horizonte: UFMG, 2010.

ZECHER, M. Finding warmth in a dark place: a glimpse of \#NuitDebout. Roar Magazine, May 14, 2016. Disponível em: 〈https://roarmag.org/essays〉. Acesso em: 17 jun. 2016.

ZIZEK, S. A Europa à deriva. Lisboa: Objectiva, 2016.

Recebido em: 02/06/2016.

Aceito em: 17/06/2016.

\section{POLÊM!CA $\mid$ LABORE}

